\title{
Ultrasound and Ozone Processing of Cashew Apple Juice: Effects of Single and Combined Processing on the Juice Quality and Microbial Stability
}

\author{
Thatyane Vidal Fonteles ${ }^{1}$, Maria Karolina de Araújo Barroso ${ }^{2}$, Elenilson de Godoy Alves Filho ${ }^{1}$, \\ Fabiano Andre Narciso Fernandes ${ }^{2}$ and Sueli Rodrigues ${ }^{1, *}$ \\ 1 Department of Food Engineering, Federal University of Ceara, Fortaleza 60440-900, Brazil; \\ thatyanevidalfonteles@ufc.br (T.V.F.); elenilson.godoy@ufc.br (E.d.G.A.F.) \\ 2 Department of Chemical Engineering, Federal University of Ceara, Fortaleza 60455-760, Brazil; \\ mariakarolinaaraujo@yahoo.com.br (M.K.d.A.B.); fabiano@ufc.br (F.A.N.F.) \\ * Correspondence: sueli@ufc.br; Tel.: +55-85-3366-9656
}

check for updates

Citation: Fonteles, T.V.; Barroso, M.K.d.A.; Alves Filho, E.d.G.;

Fernandes, F.A.N.; Rodrigues, S.

Ultrasound and Ozone Processing of Cashew Apple Juice: Effects of Single and Combined Processing on the Juice Quality and Microbial Stability. Processes 2021, 9, 2243. https:// doi.org/10.3390/pr9122243

Academic Editor: Anet

Režek Jambrak

Received: 24 November 2021 Accepted: 9 December 2021

Published: 13 December 2021

Publisher's Note: MDPI stays neutral with regard to jurisdictional claims in published maps and institutional affiliations.

Copyright: (C) 2021 by the authors Licensee MDPI, Basel, Switzerland. This article is an open access article distributed under the terms and conditions of the Creative Commons Attribution (CC BY) license (https:/ / creativecommons.org/licenses/by/ $4.0 /)$.

\begin{abstract}
Standalone and sequential ultrasound (US) and ozone (OZ) processes were applied to cashew apple juice. An unsupervised method, by principal component analysis (PCA), was used to understand the effect of the non-thermal treatments on the cashew apple composition. The US processing $\left(373 \mathrm{~W} / \mathrm{cm}^{2} ; 10 \mathrm{~min} ; 40{ }^{\circ} \mathrm{C}\right)$ promoted the highest peroxidase inactivation and increased the flavonoid content and antioxidant activity (DPPH ABTS and FRAP methods). The ozone processing $\left(0.24 \mathrm{mg} \mathrm{O}_{3} / \mathrm{mL}\right)$ increased total phenolic compounds (TPC). Sequential processing was carried out by applying both of the processes, using the best processing conditions for US and OZ. Sequential processing resulted in the higher retention of yellow flavonoids than in the control and single processing. However, the effect of sequential US and OZ processing can be deleterious to vitamin C and TPC after 30 days of cold storage while maintaining the flavonoids of the cashew apple juice. Furthermore, the synergy between US and OZ reduced native microbiota counts, suggesting a microbiologically safe juice. Further studies on the mechanism of bioactive compound degradation might be helpful for product quality modulation.
\end{abstract}

Keywords: sonication; ozone; Anacardium occidentale L.; principal component analysis; hurdle technology

\section{Introduction}

Non-thermal technologies meet consumer demand regarding fresh and safe products with high nutritional quality and appropriate shelf-life. They primarily aim to achieve microbiological stability with minimum loss of food nutrition and quality characteristics [1]. The processing approach proposed by Leistner is a rational combination of different preservation factors or techniques called "hurdles" to achieve multi-target, mild, but reliable preservation effects [2]. Recently, combinations of thermal and non-thermal technologies have been tested as "hurdle" technologies in order to extend the shelf-life and retain the quality of juices [3].

US processing is one of the non-thermal technologies that can be applied to improve the shelf-life without changing the quality attributes of fruit juices. However, due to the low lethality of US, several microorganisms can survive the process. Thus, US processing is often combined with pressure, heat, or both to ensure a higher lethality. Thermosonication is the process where US and moderate heat are applied simultaneously. Thermosonication can promote enzyme and microbial inactivation with a reduced processing time [3]. However, during thermosonication, some bioactive compounds, such as carotenoids, phenolics, and ascorbic acid, may be affected [4].

The combination of non-thermal technologies is an alternative which can be used to retain the bioactive compounds of fruit juices. Combining US with other innovative 
techniques can reduce equipment size, provide a faster response to process control and start-up, increase production, and eliminate processing steps [4]. Some studies have reported the combined processing of US with other non-thermal technologies, such as plasma, pulsed electric fields, high pressure, and OZ [5-9].

OZ processing is a technology used to achieve food safety. OZ uses in the food industry include water and wastewater treatment and sanitization for meat and dairy products, vegetables, and fruits, since ozone gas is generally regarded as safe (GRAS) and suitable for food processing [10]. OZ presents a high oxidizing power that results in an efficient microbial inactivation through cell disruption due to oxidation. OZ molecules and free radicals, generated by OZ decomposition, react with several organic compounds. Thus, they can exert positive or negative changes in the bioactive compound compositions of fruit juices [11].

When combined with US, OZ processing significantly reduced the contamination of açai juice [12]. Traore et al. [6] also reported promising results when combining $\mathrm{OZ}$ with US as an alternative for maintaining the color and vitamin $C$ content of green cabbage. Therefore, the combination of mechanical (US) and chemical effects (OZ) on food processing might preserve the fruit juices' thermolabile compounds. The effect of non-thermal processing imparts different changes on the food matrices and is strongly dependent on them.

The cashew apple (Anacardium occidentale L.) is the cashew peduncle; also named pseudofruit. The actual fruit is the nut, which corresponds to about $10 \%$ of the cashew's weight. Cashew apple corresponds to about $90 \%$ of the whole fruit weight and is composed of carbohydrates, dietary fiber, vitamins (mainly vitamin C), minerals, and antioxidant phenols $[13,14]$. In addition, the cashew apple peduncle has an attractive taste, and the flavor is used to develop several food products, such as beverages and candies $[15,16]$. In Brazil, the ripe cashew fruit is harvested from August to January.

This study evaluated the effects of single and combined processing of US and OZ on the main bioactive compounds of cashew apple juice and their chemical and microbiological stability throughout cold storage.

\section{Materials and Methods}

\subsection{Juice Preparation}

Non-pasteurized cashew apple frozen pulp, without preservatives, was purchased directly from the manufacturer (Fortaleza, Ceara, Brazil). The pulp was diluted (1:3 w/v) with potable water and immediately processed following the experimental design.

\subsection{Thermal and Non-Thermal Processing}

\subsubsection{Thermal Pasteurization}

For comparative purposes, cashew apple juice was thermally pasteurized (PAST). For PAST, cashew apple juice $(250 \mathrm{~mL})$ was transferred to a sterile flask and pasteurized at $90{ }^{\circ} \mathrm{C}$ for $1 \mathrm{~min}$ in a water bath (Marconi, model MA126, 1600 Watts, Piracicaba, SP, Brazil) [17]. A thermometer monitored the juice temperature during the PAST process. Samples were cooled immediately after PAST and stored at $4{ }^{\circ} \mathrm{C}$ until further analysis.

\subsubsection{Ultrasound Processing}

The sonication for cashew apple juice was carried out using a $500 \mathrm{~W} / 19 \mathrm{kHz}$ US processor (Unique ${ }^{\circledR}$ DES500, São Paulo, Brazil) with a $1.3 \mathrm{~cm}$ diameter titanium probe. Cashew apple juice $(100 \mathrm{~mL})$ was placed in a $250 \mathrm{~mL}$ jacketed glass reactor with temperature controlled by an external circulating water bath. Cashew apple processing was carried out with the US probe submerged $1.5 \mathrm{~cm}$ below the juice surface, input power of $100 \%(500 \mathrm{~W})$ corresponding to a power density of $373 \mathrm{~W} / \mathrm{cm}^{2}$. Processing time ranged from 2 to $10 \mathrm{~min}$, and temperature from 20 to $40{ }^{\circ} \mathrm{C}$ (Table 1). 
Table 1. Experimental parameters applied to thermal and non-thermal processing of cashew apple juice.

\begin{tabular}{|c|c|c|}
\hline Processing & Samples & Processing Parameters \\
\hline PAST & PAST & $90^{\circ} \mathrm{C} \pm 2{ }^{\circ} \mathrm{C} / 1 \mathrm{~min}$ \\
\hline \multirow{8}{*}{ US } & US1 & $75 \mathrm{~W} / \mathrm{cm}^{2} ; 2 \mathrm{~min} ; 20^{\circ} \mathrm{C}$ \\
\hline & US2 & $75 \mathrm{~W} / \mathrm{cm}^{2} ; 2 \mathrm{~min} ; 40^{\circ} \mathrm{C}$ \\
\hline & US3 & $75 \mathrm{~W} / \mathrm{cm}^{2} ; 10 \mathrm{~min} ; 20^{\circ} \mathrm{C}$ \\
\hline & US4 & $75 \mathrm{~W} / \mathrm{cm}^{2} ; 10 \mathrm{~min} ; 40{ }^{\circ} \mathrm{C}$ \\
\hline & US5 & $373 \mathrm{~W} / \mathrm{cm}^{2} ; 2 \mathrm{~min} ; 20{ }^{\circ} \mathrm{C}$ \\
\hline & US6 & $373 \mathrm{~W} / \mathrm{cm}^{2} ; 2 \mathrm{~min} ; 40{ }^{\circ} \mathrm{C}$ \\
\hline & US7 & $373 \mathrm{~W} / \mathrm{cm}^{2} ; 10 \mathrm{~min} ; 20^{\circ} \mathrm{C}$ \\
\hline & US8 & $373 \mathrm{~W} / \mathrm{cm}^{2} ; 10 \mathrm{~min} ; 40{ }^{\circ} \mathrm{C}$ \\
\hline \multirow{3}{*}{$\mathrm{OZ}$} & OZ1 & $0.08 \mathrm{mg} \mathrm{O}_{3} / \mathrm{mL}$ of juice \\
\hline & OZ2 & $0.16 \mathrm{mgO}_{3} / \mathrm{mL}$ of juice \\
\hline & OZ3 & $0.24 \mathrm{mg} \mathrm{O}_{3} / \mathrm{mL}$ of juice \\
\hline \multirow{2}{*}{ Sequential processing } & $\mathrm{US}+\mathrm{OZ}$ & $\begin{array}{l}\mathrm{US}\left(373 \mathrm{~W} / \mathrm{cm}^{2} ; 10 \mathrm{~min} ; 40^{\circ} \mathrm{C}\right) \\
\text { followed by OZ }\left(0.24 \mathrm{mg} \mathrm{O}_{3} / \mathrm{mL}\right)\end{array}$ \\
\hline & OZ+US & $\begin{array}{l}\mathrm{OZ}(0.24 \mathrm{mg} \mathrm{O} / \mathrm{mL}) \\
\text { followed by US }\left(373 \mathrm{~W} / \mathrm{cm}^{2} ; 10 \mathrm{~min} ; 40^{\circ} \mathrm{C}\right)\end{array}$ \\
\hline
\end{tabular}

\subsubsection{Ozonation}

The cashew apple juice $(100 \mathrm{~mL})$ was subjected to $\mathrm{OZ}$ processing in a glass column reactor with $4.5 \mathrm{~cm}$ diameter and $30 \mathrm{~cm}$ height. The reactor was built with a gas distributor plate made of sintered porous glass (pore size of $40-50 \mu \mathrm{m}$ ) at the reactor bottom with the same reactor diameter, allowing for a uniform distribution of the tiny OZ bubbles [15]. The reactor was coupled to a portable OZ generator (model O\&L15, Ozone Life, São José dos Campos, São Paulo, Brazil) and fed by an oxygen tank with a flow rate of $125 \mathrm{~mL} / \mathrm{min}$, corresponding to an $\mathrm{OZ}$ flow rate of $0.37 \mathrm{mg} \mathrm{O} / \mathrm{mL} / \mathrm{min}$. The ozonation was kept for 2, 4, and $6 \mathrm{~min}$, generating $0.08 \mathrm{mg} \mathrm{O} / \mathrm{mL}, 0.16 \mathrm{mg} \mathrm{O} 3 / \mathrm{mL}$, and $0.24 \mathrm{mg} \mathrm{O}_{3} / \mathrm{mL}$ of juice, respectively. These OZ loads were based on the minimum charge necessary $(0.075 \mathrm{mg} \mathrm{O} / 3 / \mathrm{mL})$ for $5 \log \mathrm{CFU} / \mathrm{mL}$ inactivation of Escherichia coli in orange juice [18]. Cashew apple processing was performed in duplicate, and the analyses were carried out in triplicate.

\subsubsection{Sequential Processing}

Two sequential processes (US.OZ and OZ.US) were carried out to evaluate their effects on cashew apple juice quality. Firstly, a volume of $100 \mathrm{~mL}$ of juice was placed in a glass jacketed reactor $(250 \mathrm{~mL})$ and sonicated for $10 \mathrm{~min}$ at a power density of $373 \mathrm{~W} / \mathrm{cm}^{2}$ at $40{ }^{\circ} \mathrm{C}$. An external circulating water bath controlled the temperature. Then, the sample volume was transferred to the gas bubble reactor for $\mathrm{OZ}$ processing at $0.24 \mathrm{mg} \mathrm{O} / \mathrm{mL}$ for $6 \mathrm{~min}$. The inverse sequence with OZ exposure, before US processing, was also carried out. The combined non-thermal treatments were carried out at the best operating conditions regarding the retention of bioactive compounds and microbial counts of each non-thermal treatment. Table 1 summarizes the operating conditions for cashew apple processing.

\subsection{Quantification of Bioactive Compounds}

Vitamin C concentration was determined spectrophotometrically according to the method of Selimović et al. [19]. The concentration of TPC was determined according to the Folin-Ciocalteu method [20] with adaptations described by Linhares et al. [21]. Finally, flavonoids were quantified as described by Francis [22]. All analyses were carried out in triplicate. Retention of vitamin C, TPC, and flavonoids were calculated, considering the untreated sample (control) as $100 \%$. 
The total antioxidant activity of the cashew apple juices was measured by ABTS (2,2azino-bis-3-ethylbenzothiazoline-6-sulfonic acid), DPPH (2,2-diphenyl-1-picrylhydrazyl), and FRAP (ferric reducing antioxidant power) methods, following the methodology presented by Linhares et al. [21].

\subsection{Polyphenol Oxidase and Peroxidase Activity}

The polyphenol oxidase (PPO) and peroxidase (POD) enzyme activities were determined according to Fonteles et al. [23].

\subsection{Microbial Storage Stability}

The juice $(100 \mathrm{~mL})$ was prepared and processed as described earlier and stored in clear glass bottles at $4{ }^{\circ} \mathrm{C}$ until the microbial stability remained. The samples were taken immediately after processing and after 15 and 30 days of storage, which is the maximum expected shelf-life of pasteurized fruit juices. Each sample was placed in a separate bottle to avoid cross-contamination. Microbial counts of total mesophilic aerobic bacteria microorganisms (TMAM), and yeasts and molds (Y\&M) were used as a quality indicator during shelf-life according to the methods described by the American Public Health Association [24] as they are common spoiling contaminants in fruit juices [21]. Salmonella and coliforms were absent from the raw and processed samples, in agreement with the Brazilian regulation for fruit juices stored under refrigeration [25]. After serial dilution, colony-forming units (CFU) were used as the microorganism count method. The spread plate count technique was used in triplicate for each dilution. The number of individual colonies on an agar plate was determined after appropriate incubation at $37^{\circ} \mathrm{C}$ for $48 \mathrm{~h}$ and $25^{\circ} \mathrm{C}$ for 5 days for TMAM and Y\&M count. The colony-forming units per $\mathrm{mL}(\mathrm{CFU} / \mathrm{mL})$ counts were converted into log values. The differences between the treated and untreated samples for each experiment were calculated as log reduction factors.

Analyses, including vitamin C, TPC, flavonoids, and total antioxidant activities (DPPH, ABTS, and FRAP), were determined at the start of the experiment and throughout the cold storage period.

\subsection{Multivariate Statistical Analysis}

Three numerical matrices were constructed using the following properties from the cashew apple juices before and after different processing: concentrations of vitamin C, TPC, and flavonoids, POD enzymatic activity, and antioxidant activity attained by the DPPH, ABTS, and FRAP methods. The first numerical matrix presented the properties from all of the samples before (control) and after different processing related to PAST, OZ, and US was developed in triplicate (Table 1). Another numerical matrix was constructed using only the selected processing according to the relevance of the results based on the juice properties (OZ3 and US8) obtained by combining the two following processes: OZ3 followed by US8 and US3 followed by OZ3. Finally, the last numerical matrix was constructed using the stability data from the samples before (control) and after PAST, and the combined non-thermal processing (OZ followed by US, US followed by OZ) was developed in nine replicates. Therefore, the matrices were presented dimensionality of 273 data points for initial evaluation (39 samples $\times 7$ juice properties), 126 data points for combined processing evaluation (18 samples $\times 7$ juice properties), and 252 data points for the juice stability (36 samples $\times 7$ juice properties).

Therefore, to explore the cashew apple properties (vitamin C, TPC, flavonoids, POD, DPPH, ABTS, and FRAP), and to understand the relationship among the juices' properties and experimental variables, an unsupervised method by PCA (principal component analysis) was applied on the numerical matrices. For multivariate statistical analyses, the data were autoscaled (mean-centered with subsequent variance scaling). The singular value decomposition (SVD) algorithm was applied to decompose each complex matrix in scores and loadings matrices. The software PLS Toolbox ${ }^{\mathrm{TM}}$ (version 8.6.2, Eigenvector Research Incorporated, Manson, WA, USA) within the MATLAB ${ }^{\mathrm{TM}}$ computational environment was 
used to develop the multivariate statistical evaluations. The relevant information of the sample's variability was obtained for all models using two principal component axes (PC1 and PC2), under a confidence level of 95\% [26].

\section{Results and Discussion}

The contents of vitamin C, TPC, and flavonoids, the POD enzyme activity, and the antioxidant activity (DPPH, ABTS, and FRAP methods) were determined for the cashew apple juice samples after thermal and non-thermal processing (Table 1) and the non-processed sample (control). The vitamin C and TPC contents were used as bioactive indicators to assess the impact of non-thermal processing because these compounds represent the most abundant bioactive substances found in cashew apple juice.

Since the numerical matrices presented high dimensionality and complexity, multivariate statistical analyses by PCA explored the juices' changes due to the different processes. Figure 1 shows the effect of single non-thermal processing (OZ and US-Table 1) on cashew apple juice compared to the thermal PAST $\left(90 \pm 2{ }^{\circ} \mathrm{C}\right)$. The PCA biplot in Figure 1 depicts the quality parameters for the unprocessed juice (control, green), pasteurized (red), US processed (dark blue), OZ processed samples (light blue).

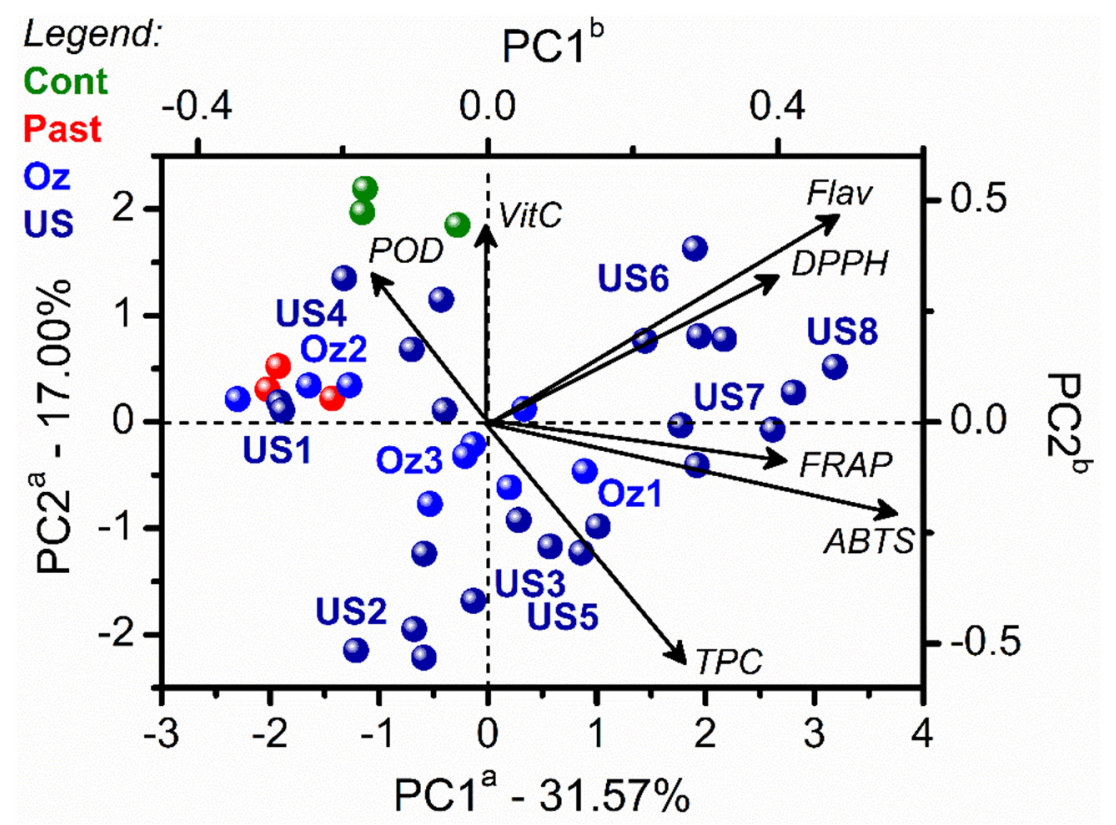

Figure 1. PCA biplot (scores and loadings) from cashew apple juices before (control, green) and after thermal PAST (red), non-thermal processing by OZ (light blue), and US (dark blue). See details in Table 1. The letter a in the PC axes refers to scores axes, and b refers to loadings axes with variables represented by vectors from the origin.

The juices processed by US at $75 \mathrm{~W} / \mathrm{cm}^{2}$ (US1, US2, and US3), grouped at negative values of PC2, induced high values of TPC. The juices processed at $373 \mathrm{~W} / \mathrm{cm}^{2}$ (US6, US7, and US8) were grouped at positive values of PC2. The US8 condition favored high values of flavonoids, DPPH, FRAP, and ABTS and the highest inactivation of POD. US power density directly affected the TPC concentration in cashew apple juice, increasing $33 \%$ of yellow flavonoids in the US8 $\left(373 \mathrm{~W} / \mathrm{cm}^{2} ; 10 \mathrm{~min} ; 40{ }^{\circ} \mathrm{C}\right)$ condition. US intensity is the energy emitted per second per area of the emitting surface, which relates to the amplitude of the transducer and the sound wave. Higher amplitudes are associated with more significant collision between the bubbles originating from the cavitation and the sample, resulting in cell wall destruction with higher extractability of the bioactive compounds [27].

At the lowest power intensities, the process temperature influenced the TPC content of the cashew apple juice, increasing by $57 \%$ after processing at US3 condition $\left(75 \mathrm{~W} / \mathrm{cm}^{2}\right.$; $10 \mathrm{~min}$ and $\left.20^{\circ} \mathrm{C}\right)$ and decreasing by $54 \%$ at US4 condition $\left(75 \mathrm{~W} / \mathrm{cm}^{2} ; 10 \mathrm{~min}\right.$ and $\left.40{ }^{\circ} \mathrm{C}\right)$. 
US processed juices at higher power intensities (US5-8) presented higher antioxidant capacity measured by ABTS, FRAP, and DPPH, which can be correlated to higher TPC and yellow flavonoids (Figure 1). This result could also be correlated to the differences in the vapor pressure due to temperature rise. Higher vapor pressure decreases the effectiveness of the cavitation process and leads to lower extraction efficiency. However, higher temperatures also increase cavitation bubbles, increasing the contact area and diffusion between the solid and the solvent [27]. Guerrouj et al. [28] reported that sonication of orange juice for 10,20 , and $30 \mathrm{~min}$ at $43-45^{\circ} \mathrm{C}$ enhanced the bioactive compounds (total phenolics, flavonoids, carotenoids, anthocyanins, and ascorbic acid) and microbiological quality of orange juice compared with unprocessed samples.

Despite the phenolics' susceptibility to OZ [29], processing favored increased cashew apple juice TPC instead of vitamin C, reaching an increment of $40 \%$ at OZ3 conditions $\left(0.24 \mathrm{mg} \mathrm{O}_{3} / \mathrm{mL}\right)$. The higher TPC after ozonation may be related to an extraction effect caused by OZ that overlaps a possible degradation of the phenolic compounds. Similarly, Noguera et al. [30] reported higher amounts of total phenolics in orange juice, and they attributed this result to the detachment of conjugated cell wall phenolics after OZ processing.

US processing increased the vitamin $C$ content of the cashew apple juice, reaching an $8 \%$ increment at US8. This increase occurred due to the mechanical effects of US processing that impart particle size reduction and damage of cells, improving the mass transfer and the extraction rate $[27,31]$.

Conversely, vitamin C degradation ranged from 3 to $11 \%$ for all of the $\mathrm{OZ}$ treatments evaluated for cashew apple juice processing. This reduction could be due to the strong oxidation potential of OZ [32]. On the other hand, vitamin C was highly retained in the OZ-treated cantaloupe juices (68\%) compared with the pasteurized ones (39\%) using $7.7 \mathrm{gO}_{3} / \mathrm{L}$ [33].

Polyphenol oxidase (PPO) activity was not detected in the cashew apple juice. Therefore, the PPO absence might be attributed to the cashew apple variety. Non-thermal processing (US and OZ) achieved a satisfactory POD inactivation compared to the thermal pasteurized juice. However, US processing at $40{ }^{\circ} \mathrm{C}\left(373 \mathrm{~W} / \mathrm{cm}^{2} ; 10 \mathrm{~min} ; 40^{\circ} \mathrm{C}\right)$ promoted a higher POD inactivation $(p<0.05)$ than US processing at $20^{\circ} \mathrm{C}$, in contrast with the previous results. This behavior may have occurred due to the synergistic effect of temperature and cavitation.

In conclusion, standalone US or OZ exposure is comparable in its impact on cashew apple juice bioactive compounds. US processing, at $373 \mathrm{~W} / \mathrm{cm}^{2}$ for $10 \mathrm{~min}$ at $40{ }^{\circ} \mathrm{C}$ (US8), favored high values of flavonoids and antioxidant activity in the cashew apple juice, along with the highest inactivation of POD compared to $\mathrm{OZ}$ processing. In addition, thermal PAST resulted in a vitamin $C$ and TPC composition similar to the unprocessed juice, with a higher inactivation of POD $(95 \%)(p<0.05)$.

Therefore, after understanding the effects of the standalone thermal and non-thermal processes on cashew apple juice quality, the impact of sequential non-thermal processing was evaluated. Moreover, the order of the application of the non-thermal hurdle processing was evaluated, considering that this could be an essential factor for the microbial inactivation and preservation of bioactive compounds of cashew apple juice.

Based on the previous results, the non-thermal combined treatments were as follows: OZ3 $\left(0.24 \mathrm{mg} / \mathrm{mL}\right.$ of juice) followed by US8 $\left(100 \mathrm{~W} / \mathrm{cm}^{2}\right.$ for $10 \mathrm{~min}$ at $\left.40{ }^{\circ} \mathrm{C}\right)$ and US8 followed by OZ3. The effect of the sequential processing was compared to all non-thermal processing, PAST (Table 1), and unprocessed juice (control).

Figure 2 presents the discrimination of the samples based on the PC1 axis, with $\mathrm{OZ}$ and US sequential non-thermal processing at negative scores. The PAST and single $\mathrm{OZ}$ (OZ3) and US (US8) processing clustered with the control samples at positive scores. Combined non-thermal processing affected ABTS, DPPH, and flavonoids values, mainly when OZ followed US. On the other hand, PAST, OZ3, and US8 conditions presented relevant effects on POD, FRAP, TPC, and vitamin C values, mainly after US8. The juices 
after US8 processing showed similar characteristics to the unprocessed juices, while the juices after OZ3 processing presented similar characteristics with the pasteurized ones.

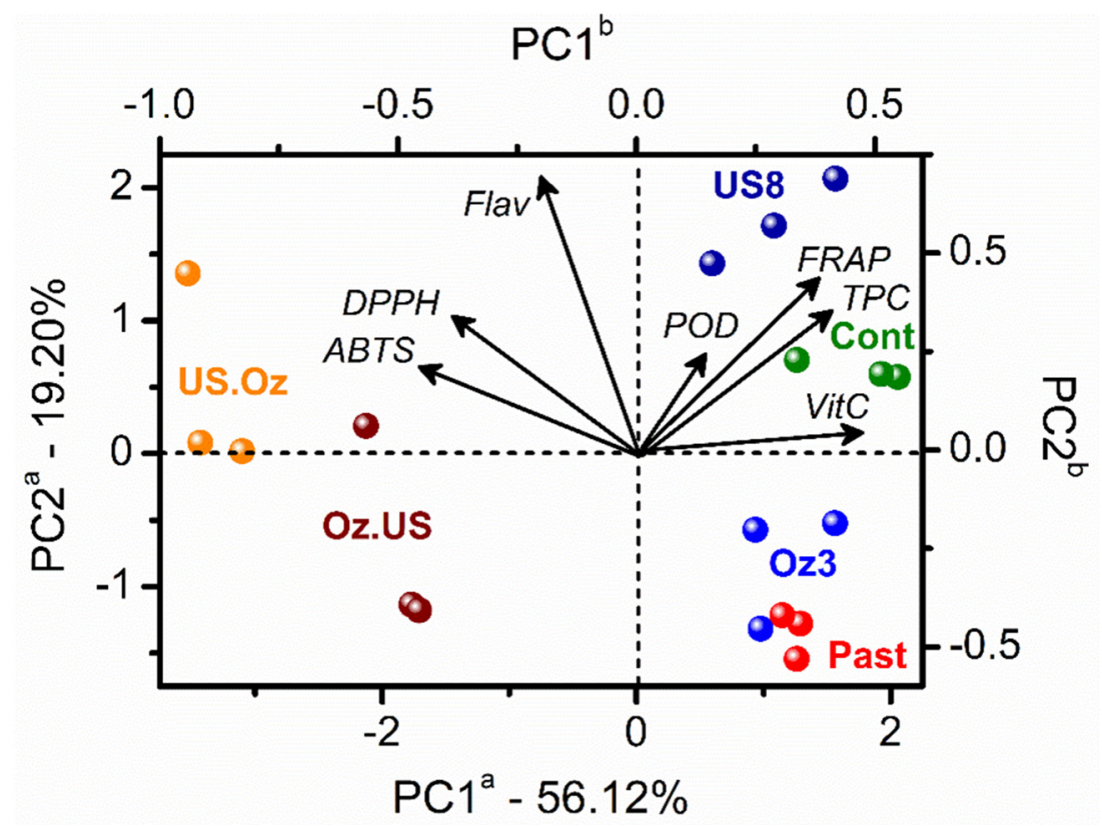

Figure 2. PCA biplot (scores and loadings) from cashew apple juices before (control in green color) and after thermal processing by PAST (red), and the sequential non-thermal processing by OZ (OZ3) followed by US (US8) and vice versa. See details in Table 1. The letter a in the PC axes refers to score axes, and $b$ refers to loadings axes with variables represented by vectors from the origin.

Sequential processing (US.OZ or OZ.US) presented higher $(p<0.05)$ retention of yellow flavonoids than the control and standalone processing, indicating that the combined treatment can be recommended to maintain the flavonoid content of cashew apple juice. The results are in agreement with the study by Zia et al. [34], where the US $\left(24 \mathrm{kHz}, 20^{\circ} \mathrm{C}\right.$ for $20 \mathrm{~min}$ ) combined with microwave (MW) $(2450 \mathrm{MHz}, 120 \mathrm{~s})$ was more effective in preserving TPC and flavonoids in sugarcane juice. The combined treatment was superior to standalone US and MW treatments. The higher content of TPC and flavonoids was attributed to POD inactivation since this enzyme utilizes these compounds as a substrate, causing their degradation.

Sequential processing, and its order, presented relevant effects on cashew apple juice vitamin C retention. A reduction of 40 and $50 \%$ was observed for OZ.US and US.OZ, respectively. On the other hand, the pasteurized juices increased in vitamin $C$ by $3 \%$. Thus, after $\mathrm{OZ}$ processing, vitamin $\mathrm{C}$ degradation might be more influenced by contact with air than by the temperature [4].

\subsection{Storage Stability}

Since sequential non-thermal processing (OZ3 followed by US8 and vice versa) presented a significant and relevant influence on the cashew apple juice properties, a study of shelf-life stability was performed during cold storage $\left(4^{\circ} \mathrm{C}\right)$. The results were also compared to PAST and unprocessed (control) samples. Figure 3 illustrates the PCA results after cold storage $(0,15$, and 30 days).

The type of processing was the main factor for sample discrimination, with the sequential non-thermal processes at negative scores and PAST clustered with the control sample at positive scores. Both sequential non-thermal processes favored high values of flavonoids. The control samples, and the other processes clustered at positive scores, favored high POD, DPPH, ABTS, FRAP, vitamin C, and TPC values. Similarly, Traore et al. [6] also reported increased TPC and flavonoid contents of cabbage after US ( $40 \mathrm{kHz}$, 8 and $20 \mathrm{~min}$ ) and US.OZ at $0.7 \mathrm{mg} / \mathrm{L}$ for $8 \mathrm{~min}$ processing when compared to the control. 


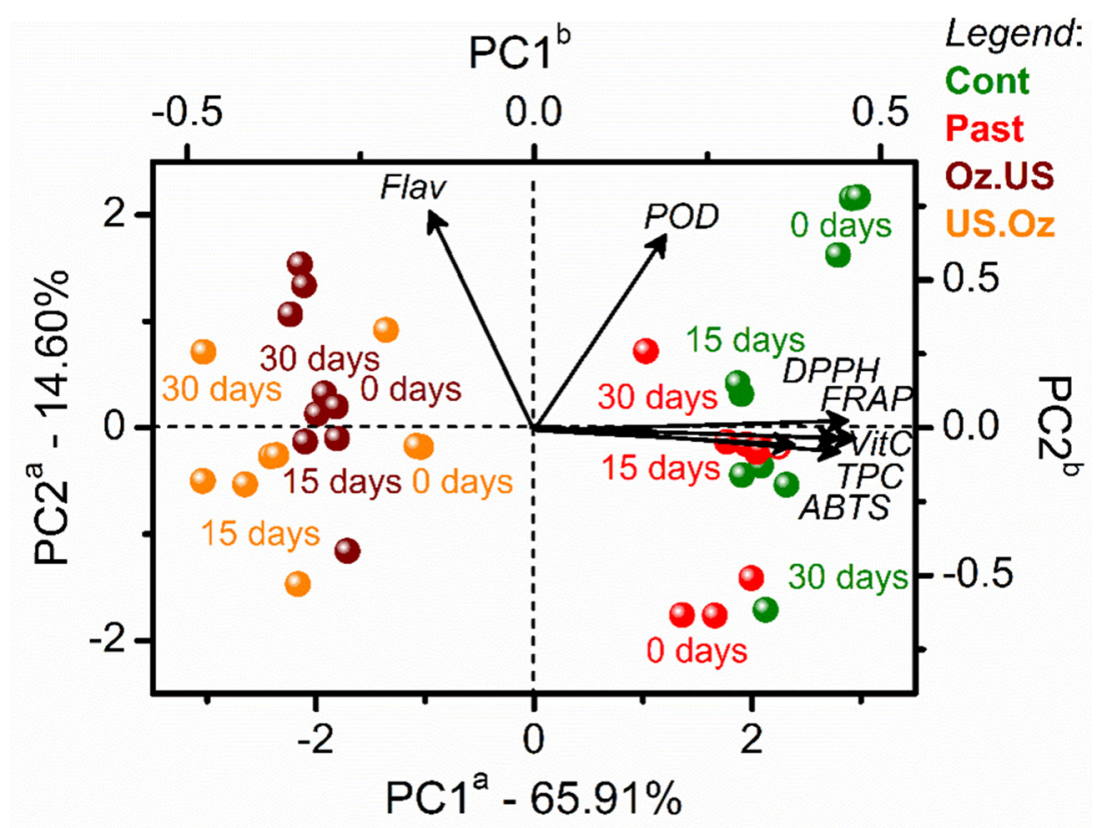

Figure 3. PCA biplot (scores and loadings) of the stability of cashew apple juices (control, in green), after thermal processing by PAST (red), and after sequential non-thermal processing by OZ (OZ3) followed by US (US8) and vice versa. The juices' stability was analyzed after 0,15 , and 30 days. The letter $a$ in the PC axes refers to scores axes, and $b$ refers to loadings axes with variables represented by vectors from the origin.

The influence of each treatment (control, PAST, OZ.US, and US.OZ) and their stability periods were evaluated separately to better detail the storage stability responses, highlighting the variability of the samples. Figure 4 presents the PCA results from the stability of the control juices (a), PAST (b), OZ.US (c), and US.OZ (d) processed samples.

All of the samples presented the same score tendency based on the evolution of the stability period, from positive ( 0 days, in blue) to negative scores of PC1 (30 days, in red), independent of the process. The respective loadings described differences according to the sample's properties (POD, DPPH, ABTS, FRAP, vitamin C, TPC, and flavonoids). The storage for 30 days influenced high values of ABTS for the unprocessed samples (Figure 4a), the samples processed by PAST (Figure 4b), and the samples processed by OZ followed by US (Figure 4c). High amounts of flavonoids were observed in samples processed by OZ followed by US. All of the variables (POD, DPPH, ABTS, FRAP, vitamin C, TPC, and flavonoids) were high for the US.OZ processed samples at day 0 (Figure $4 \mathrm{~d}$ ). High concentrations of flavonoids, TPC, and vitamin $C$ were observed mainly at 0 days in the unprocessed, pasteurized, and US.OZ processed juices. PAST did not negatively affect the concentration of the bioactive compounds of the cashew apple juice. However, the ascorbic acid content was reduced by $20 \%$ during the storage period. Figure 5 presents the PCA results from the stability periods evaluated separately at 0 (a), 15 (b), and 30 days (c).

The effect of the sequential non-thermal processing order (OZ followed by US and vice versa) were similar, as indicated by their clustering at negative scores of PC1 for all stability periods $(0,15$, and 30 days). Sequential processing imparted low values of all studied variables (concentrations of vitamin C, TPC and flavonoids, POD, DPPH, ABTS, and FRAP) mainly after 15 days of storage. On the other hand, concentrations of flavonoids were still high after 30 days. Additionally, the control and PAST samples clustered at positive scores, indicating high vitamin C and TPC levels and antioxidant activity (DPPH, ABTS, and FRAP). 

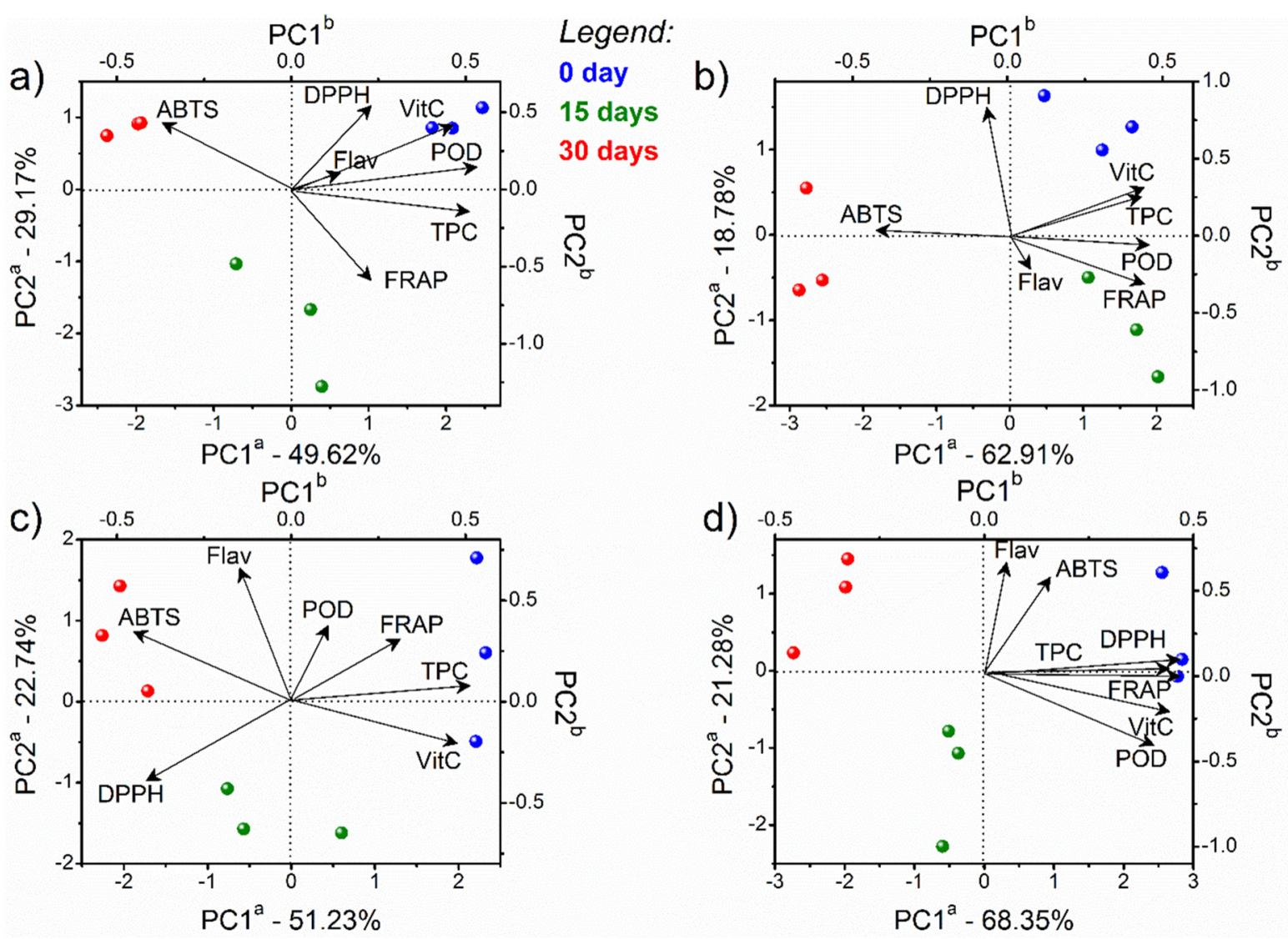

Figure 4. PCA biplot (scores and loadings) of the stability of cashew apple juices: (a) control (non-processed); (b) after thermal processing by PAST; (c) after sequential processing by OZ (Oz3) followed by US (US8), and (d) US (US8) followed by OZ (Oz3). The juices' stability was analyzed after 0 (blue), 15 (green), and 30 days (red). The letter a in the PC axes refers to scores axes, and $b$ refers to loadings axes with variables represented by vectors from the origin.

PODs are markers in food manufacturing, since their activity results in undesirable changes, such as the development of dark brown pigments [35]. Partial inactivation of POD activity for all of the evaluated processes (thermal and sequential non-thermal) was observed. The stability of POD activity during cold storage attests that processing denatured the enzyme irreversibly. US cavitation can damage cell structure, allowing the release of intracellular compounds, such as PODs, exposing them to the subsequent $\mathrm{OZ}$ processing. Free radicals produced during sonication and ozonation can be scavenged by the amino acid residues of the enzymes, affecting the enzyme structure.

PODs are present in plants as a combination of various isoenzymes with different stabilities. Therefore, sequential processing can positively affect the sensitizing POD in hurdle processing [36]. Furthermore, reducing oxidoreductases' (POD, PPO, and APXascorbate peroxidase) activity also contributes towards preserving TPC and vitamin C [31].

This study revealed that the combination of US and OZ processing in a sequential order could be deleterious to vitamin C and TPC after 30 days of cold storage. On the other hand, it is an excellent alternative to maintain the flavonoids in cashew apple juice. OZ.US processing resulted in the higher retention of TPC $(85 \%)$, vitamin C $(70 \%)$, and flavonoids $(+15 \%)$ at the end of the 30 days of cold storage. The retention of ascorbic acid in fruit juices is a quality indicator, and the juice shelf-life ends when its amount decreases to $50 \%$ [37]. 

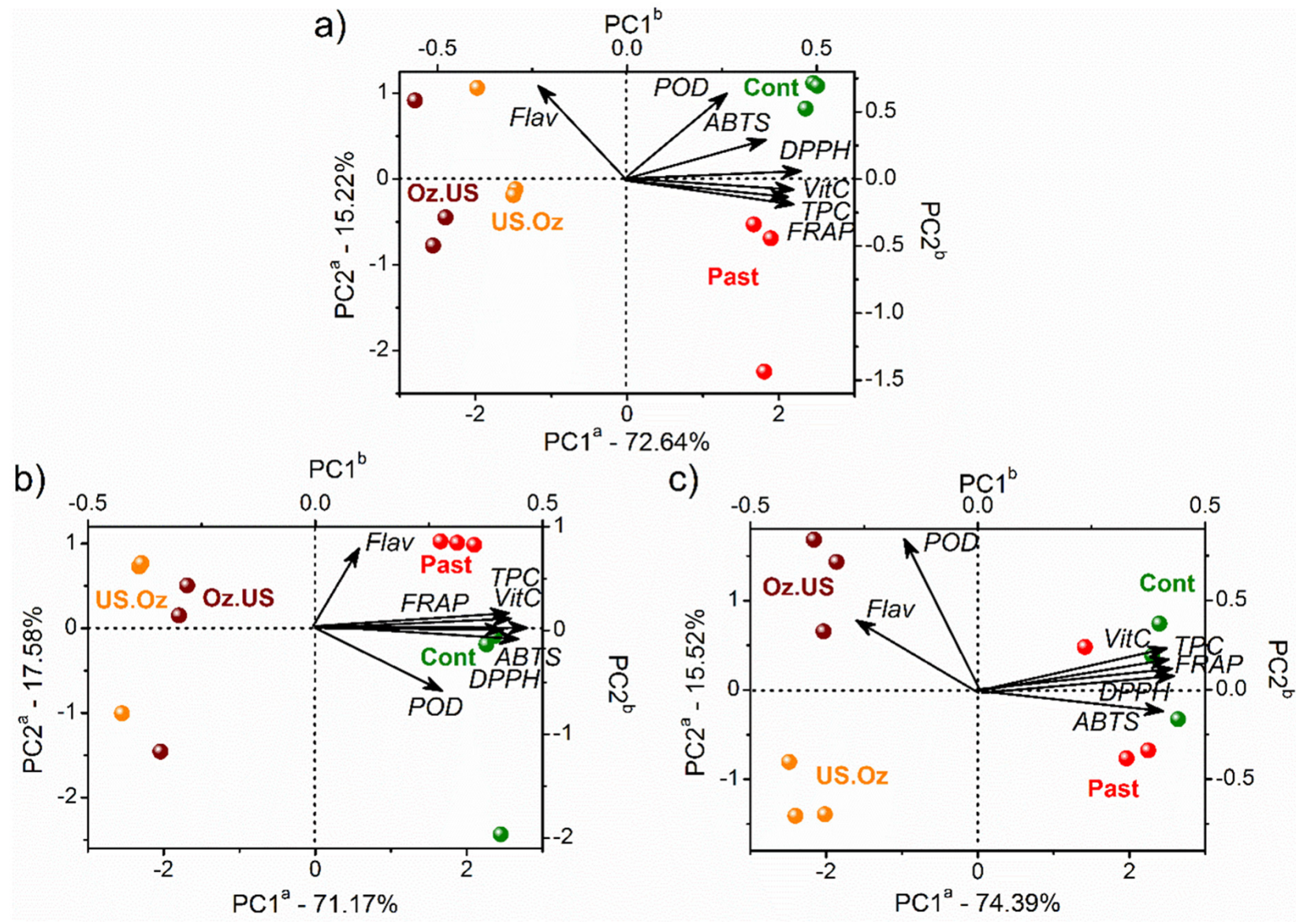

Figure 5. PCA biplot (scores and loadings) of the stability of cashew apple juices (control, in green) and after thermal processing by PAST (red), and sequential non-thermal processing by OZ (OZ3) followed by US (US8) and vice versa. The juices' stability was analyzed after 0 (a), 15 (b), and 30 days (c). The letter a in the PC axes refers to scores axes, and b refers to loadings axes with variables represented by vectors from the origin.

\subsection{Microbial Stability during Cold Storage}

The cashew apple juice presented an initial microbial load of $4.3 \pm 0.1 \log \mathrm{CFU} / \mathrm{mL}$ for TMAM (total mesophilic aerobic bacteria microorganisms) and $3.4 \pm 0.1 \log \mathrm{CFU} / \mathrm{mL}$ for Y\&M (yeasts and molds). Immediately after US processing (US8), the microbial loads were $4.7 \pm 0.4 \log \mathrm{CFU} / \mathrm{mL}$ for TMAM and $1.6 \pm 0.1 \log \mathrm{CFU} / \mathrm{mL}$ for Y\&M counts. After OZ processing (OZ3), the microbial counts were $3.3 \pm 0.1 \log \mathrm{CFU} / \mathrm{mL}$ for TMAM and $1.2 \pm 0.0 \log \mathrm{CFU} / \mathrm{mL}$ for Y\&M. Application of US, separately, cannot inactivate bacteria from cashew apple juice. As such, the US processing proposed herein is classified as a sub-lethal $\left(<45^{\circ} \mathrm{C}\right)$ thermosonication [38], and, to increase its efficacy, the hurdles should be combined.

The native microbial counts in the untreated cashew apple juice (control) increased during storage, reaching a maximum count of 6.1 and $5.1 \log$ CFU/ mL of TMAM and Y\&M after 30 days of cold storage, respectively (Figure 6). The highest TMAM counts were observed, possibly because they contained epiphytic microorganisms. The maximum acceptable microbial limits regarding TMAC and Y\&M count in fruit juices are 4-log and 3-log CFU/mL, respectively [8]. Thermal PAST $\left(90^{\circ} \mathrm{C}\right.$ for $1 \mathrm{~min}$ ) ensured low microbial counts throughout the storage period (30 days), keeping the TMAM and Y\&M counts below 1-log CFU/mL. The sequential non-thermal treatments, US.OZ and OZ.US, reduced the initial counts and kept the samples stable during the whole storage period. 

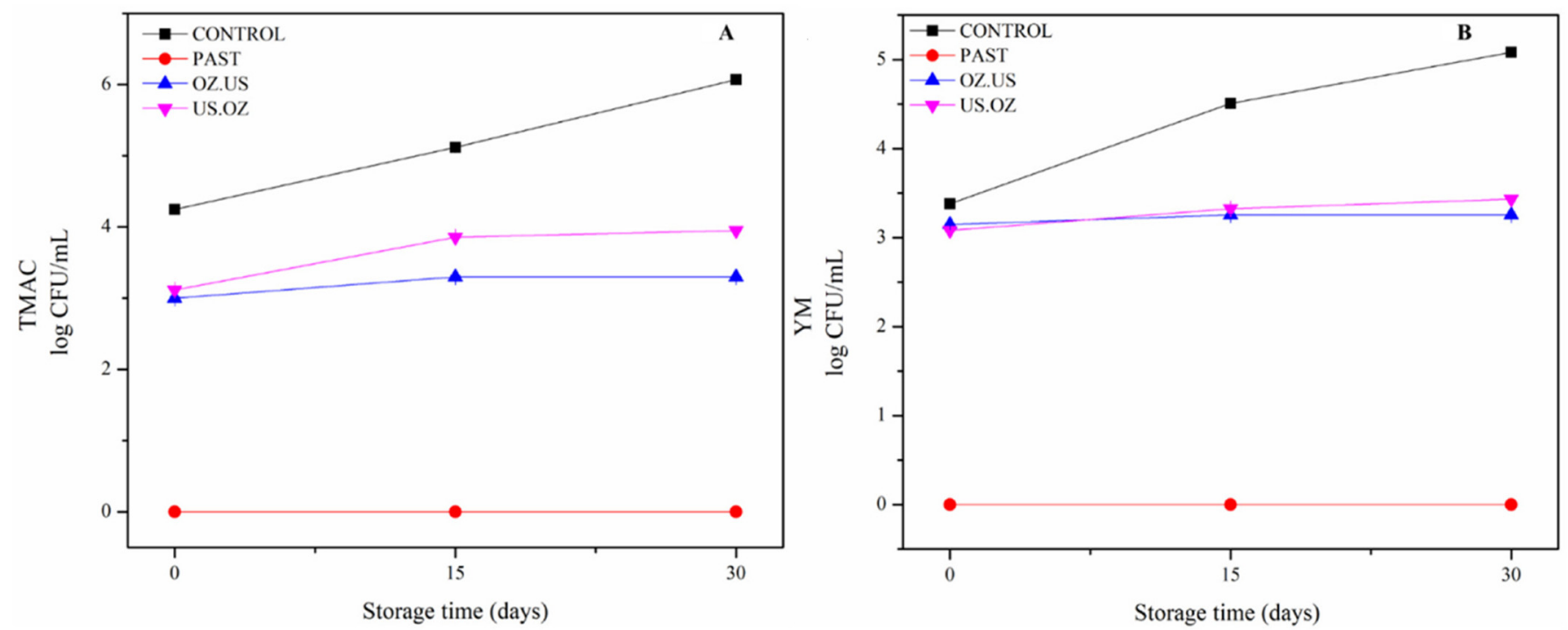

Figure 6. Total mesophilic aerobic bacteria microorganisms $(\log \mathrm{CFU} / \mathrm{mL})(\mathbf{A})$ and yeasts and molds (B) counts (log

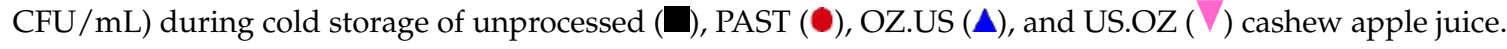

According to Anaya-Esparza [39], the bacterial cells and spores become more sensitive after thermosonication due to energy absorption by the membranes and cell structures through the combined effects of heat and US waves. The modification, erosion, and perforation of cell membranes increase the susceptibility of bacterial cells to the lethal effects. The authors emphasize that US inactivation susceptibility depends on the food matrix, processing parameters, and the type of microorganism. Traore et al. [40] reported that US processing of cabbage significantly inactivated E. coli and Salmonella cells. The authors correlated the loss of bacterial membrane integrity to the loss of the metabolic potentiality because of the lack of selective permeability and the inability to maintain the electrochemical gradients essential to microbial viability.

Table 2 shows the logarithmic reduction factor (LRF) after single and sequential non-thermal processing of the cashew apple juice. The injured cells of epiphytic biota of the cashew apple juice could not repair themselves during storage for both US.OZ and OZ.US. Processing reduced the TMAC and Y\&M count, suggesting a microbiologically safe cashew apple juice. The trend observed in this study is similar to the results reported by García-Mateos et al. on the OZ-HHP processing of pitaya juice [41].

Table 2. Logarithmic reduction factor (LRF) after single and combined non-thermal processing of cashew apple juice.

\begin{tabular}{ccccc}
\hline \multirow{2}{*}{ Sample } & \multicolumn{2}{c}{ Log CFU/mL } & \multicolumn{2}{c}{ Log Reduction Factor } \\
\cline { 2 - 5 } & TMAM & Y\&M & TMAM & Y\&M \\
\hline Control & 4.9 & 3.4 & - & - \\
US8 & 4.8 & 1.6 & 0.1 & 1.8 \\
OZ3 & 3.3 & 1.2 & 1.6 & 2.2 \\
OZ+US & 3.0 & 1.1 & 1.9 & 2.3 \\
US+OZ & 3.1 & 1.1 & 1.8 & 2.3 \\
\hline
\end{tabular}

Liao et al. [1] evaluated the combined application of US and non-thermal plasma. They observed the importance of the processing order in hurdle technology. The authors found that cold plasma pretreatment generated abundant reactive species in the medium that were subsequently driven inside the $S$. aureus cells by the ultrasonic microjet. In contrast, the US pretreatment resulted in low concentrations of reactive species in the medium to react with bacterial cells. A similar mechanism can be proposed for the US.OZ processing, following the so-called "additive effect". The free radicals formed during US 
processing led to the spontaneous formation of bactericidal hydrogen peroxide, formed by the breakdown of water during cavitation bubble collapse [42]. The decomposition of hydrogen peroxide produces free radicals that are neutralized by the natural antioxidants of the cashew apple juice, such as vitamin C, leading to some loss of bioactive compounds [43]. After US processing, high sensitivity on the microbial cell wall occurs, causing damage to the cell structure. Furthermore, $\mathrm{OZ}$ processing destroys the sensitized microorganisms by progressive oxidation of cellular components $[3,44]$.

\section{Conclusions}

Chemometrics is a valuable tool to evaluate the changes imparted, by processing, to the food matrix. The chemometric approach evaluated the cashew apple changes after standalone and sequential US or OZ processing regarding bioactive compound content and storage stability. The results of the present study show that it is possible to increase the bioactive content in cashew apple juice by US and OZ processing. Therefore, sequential processing is a suitable candidate for the conservation of cashew apple juice. The synergy between US and OZ makes it possible to obtain a microbiologically stable fruit juice with a high flavonoid content, despite some degradation of bioactive compounds, such as vitamin C. Furthermore, optimization of the processing conditions of the sequential processing could allow for modulating the concentration of the bioactive compounds in fruit juices. In further studies, the chemical characterization of the bioactive compounds' degradation might be helpful to modulate the product quality, avoiding its loss.

Author Contributions: Conceptualization, T.V.F., F.A.N.F. and S.R.; methodology, T.V.F., M.K.d.A.B. and E.d.G.A.F.; investigation, T.V.F., M.K.d.A.B., E.d.G.A.F. and S.R.; data curation, T.V.F., M.K.d.A.B., E.d.G.A.F. and S.R.; writing—original draft preparation, T.V.F. and S.R.; writing-review and editing, T.V.F. and S.R.; supervision, T.V.F., F.A.N.F. and S.R.; project administration, F.A.N.F. and S.R.; funding acquisition, F.A.N.F. and S.R. All authors have read and agreed to the published version of the manuscript.

Funding: This study was financed in part by the Coordenação de Aperfeiçoamento de Pessoal de Nível Superior-(CAPES)—Finance Code 001, FUNCAP and CNPq.

Institutional Review Board Statement: Not applicable.

Informed Consent Statement: Not applicable.

Data Availability Statement: Not applicable.

Acknowledgments: The authors acknowledge FUNCAP and CNPq through the National Institute of Science and Technology for Tropical Fruit-INCT-FT for their financial support and the scholarship. This study was financed in part by the Coordenação de Aperfeiçoamento de Pessoal de Nível Superior-(CAPES)-Finance Code 001.

Conflicts of Interest: The authors declare no conflict of interest.

\section{Abbreviations}

Ultrasound: US; Ozone: OZ; Pasteurization: PAST; Control: Cont; Total phenolic compounds: TPC; Principal Component Analysis: PCA; Generally Recognized as Safe: GRAS; (2,2-azino-bis-3ethylbenzothiazoline-6-sulfonic acid): ABTS; (2,2'-diphenyl-1-picrylhydrazyl): DPPH; Ferric reducing antioxidant power: FRAP; polyphenol oxidase: PPO; peroxidase: POD; Total mesophilic aerobic bacteria microorganisms: TMAM; yeasts and molds: Y\&M; colony-forming units per $\mathrm{mL}$ : $\mathrm{CFU} / \mathrm{mL}$; Singular Value Decomposition (SVD).

\section{References}

1. Liao, X.; Li, J.; Muhammad, A.I.; Suo, Y.; Ahn, J.; Liu, D.; Chen, S.; Hu, Y.; Ye, X.; Ding, T. Preceding Treatment of Non-Thermal Plasma (NTP) Assisted the Bactericidal Effect of Ultrasound on Staphylococcus Aureus. Food Control 2018, 90, 241-248. [CrossRef]

2. Leistner, L.; Leon, G.M. Gorris Food Preservation by Hurdle Technology. Trends Food Sci. Technol. 1995, 6, 41-45. [CrossRef] 
3. Putnik, P.; Pavlić, B.; Šojić, B.; Zavadlav, S.; Žuntar, I.; Kao, L.; Kitonić, D.; Kovačević, D.B. Innovative Hurdle Technologies for the Preservation of Functional Fruit Juices. Foods 2020, 9, 699. [CrossRef] [PubMed]

4. Aguilar, K.; Garvín, A.; Ibarz, A.; Augusto, P.E.D. Ascorbic Acid Stability in Fruit Juices during Thermosonication. Ultrason. Sonochemistry 2017, 37, 375-381. [CrossRef]

5. Khadhraoui, B.; Ummat, V.; Tiwari, B.K.; Fabiano-Tixier, A.S.; Chemat, F. Review of Ultrasound Combinations with Hybrid and Innovative Techniques for Extraction and Processing of Food and Natural Products. Ultrason. Sonochemistry 2021, 76, 105625. [CrossRef] [PubMed]

6. Traore, M.B.; Sun, A.; Gan, Z.; Long, W.Y.; Senou, H.; Zhu, Y.; Togo, J.; Fofana, K.H.; Sidibe, A.M. Assessing the Impact of the Combined Application of Ultrasound and Ozone on Microbial Quality and Bioactive Compounds with Antioxidant Attributes of Cabbage (Brassica oleracea L. Var. Capitata). J. Food Process. Preserv. 2020, 44, 1-11. [CrossRef]

7. Liao, X.; Cullen, P.J.; Muhammad, A.I.; Jiang, Z.; Ye, X.; Liu, D.; Ding, T. Cold Plasma-Based Hurdle Interventions: New Strategies for Improving Food Safety. Food Eng. Rev. 2020, 12, 321-332. [CrossRef]

8. Yildiz, S.; Pokhrel, P.R.; Unluturk, S.; Barbosa-Cánovas, G.V. Shelf Life Extension of Strawberry Juice by Equivalent Ultrasound, High Pressure, and Pulsed Electric Fields Processes. Food Res. Int. 2021, 140, 110040. [CrossRef]

9. Aadil, R.M.; Zeng, X.A.; Sun, D.W.; Wang, M.S.; Liu, Z.W.; Zhang, Z.H. Combined Effects of Sonication and Pulsed Electric Field on Selected Quality Parameters of Grapefruit Juice. LWT-Food Sci. Technol. 2015, 62, 890-893. [CrossRef]

10. Aadil, R.M.; Zeng, X.A.; Han, Z.; Sahar, A.; Khalil, A.A.; Rahman, U.U.; Khan, M.; Mehmood, T. Combined Effects of Pulsed Electric Field and Ultrasound on Bioactive Compounds and Microbial Quality of Grapefruit Juice. J. Food Process. Preserv. 2018, 42, e13507.[CrossRef]

11. Wong-paz, J.E.; Muñiz-márquez, D.B.; Aguilar-zárate, P.; Rodríguez-herrera, R.; Aguilar, C.N. Microplate Quanti Fi Cation of Total Phenolic Content from Plant Extracts Obtained by Conventional and Ultrasound Methods. Phytochem. Anal. 2014, 25, 439-444. [CrossRef]

12. Oliveira, A.F.A.; Mar, J.M.; Santos, S.F.; da Silva Júnior, J.L.; Kluczkovski, A.M.; Bakry, A.M.; de Araújo Bezerra, J.; de Cássia Saraiva Nunomura, R.; Sanches, E.A.; Campelo, P.H. Non-Thermal Combined Treatments in the Processing of Açai (Euterpe Oleracea) Juice. Food Chem. 2018, 265, 57-63. [CrossRef] [PubMed]

13. Assunçao, R.B.; Mercadante, A.Z. Carotenoids and Ascorbic Acid from Cashew Apple (Anacardium occidentale L.): Variety and Geographic Effects. Food Chem. 2003, 81, 495-502. [CrossRef]

14. Rabelo, M.C.; Fontes, C.P.M.L.; Rodrigues, S. Enzyme Synthesis of Oligosaccharides Using Cashew Apple Juice as Substrate. Bioresour. Technol. 2009, 100, 5574-5580. [CrossRef] [PubMed]

15. Sucupira, N.R.; Sabino, L.B.d.S.; Gondim Neto, L.; Gouveia, S.T.; de Figueiredo, R.W.; Maia, G.A.; de Sousa, P.H.M. Evaluation of Cooking Methods on the Bioactive Compounds of Cashew Apple Fibre and Its Application in Plant-Based Foods. Heliyon 2020, 6, e05346. [CrossRef]

16. Fonteles, T.V.; Leite, A.K.F.; da Silva, A.R.A.; Fernandes, F.A.N.; Rodrigues, S. Sonication Effect on Bioactive Compounds of Cashew Apple Bagasse. Food Bioprocess Technol. 2017, 10, 1854-1864.[CrossRef]

17. Deak, T. Thermal Treatment. Food Saf. Manag. A Pract. Guide Food Ind. 2014, 1, 423-442. [CrossRef]

18. Patil, S.; Bourke, P.; Frias, J.M.; Tiwari, B.K.; Cullen, P.J. Inactivation of Escherichia Coli in Orange Juice Using Ozone. Innov. Food Sci. Emerg. Technol. 2009, 10, 551-557. [CrossRef]

19. Selimović, A.; Salkić, M.; Selimović, A. Direct Spectrophotometric Determination of L- Ascorbic Acid in Pharmaceutical Preparations Using Sodium Oxalate as a Stabilizer. Int. J. Basic Appl. Sci. 2011, 11, 106-109.

20. Folin, O.; Ciocalteu, V. On Tyrosine and Tryptophane Determinations in Proteins. J. Biol. Chem. 1927, 73, 627-650. [CrossRef]

21. Linhares, M.d.F.D.; Alves Filho, E.G.; Silva, L.M.A.; Fonteles, T.V.; Wurlitzer, N.J.; de Brito, E.S.; Fernandes, F.A.N.; Rodrigues, S. Thermal and Non-Thermal Processing Effect on Açai Juice Composition. Food Res. Int. 2020, 136, 109506. [CrossRef] [PubMed]

22. Francis, F.J. Chapter 7-Analysis of Anthocyanins. In Markakis; Academic Press: Cambridge, MA, USA, 1982; pp. 181-207. ISBN 978-0-12-472550-8.

23. Fonteles, T.V.; Costa, M.G.M.; de Jesus, A.L.T.; de Miranda, M.R.A.; Fernandes, F.A.N.; Rodrigues, S. Power Ultrasound Processing of Cantaloupe Melon Juice: Effects on Quality Parameters. Food Res. Int. 2012, 48, 41-48. [CrossRef]

24. Downes, F.P.; Ito, K. American Public Health Association-Compendium of Methods for the Microbiological Examination of Foods; Salfinger, Y., Tortorello, M.L., Eds.; American Public Health Association: Washington, DC, USA, 2015; ISBN 978-0-87553-022-2.

25. Ministry of Health; National Health Surveillance Agency RDC N ${ }^{\circ} 12$. Available online: https:/ /www.gov.br/agricultura/pt$\mathrm{br} /$ assuntos/inspecao/produtos-vegetal/legislacao-1/biblioteca-de-normas-vinhos-e-bebidas/resolucao-rdc-no-12-de-2-dejaneiro-de-2001.pdf (accessed on 29 November 2021).

26. De Souza Carvalho, L.M.; Lemos, M.C.M.; Sanches, E.A.; da Silva, L.S.; de Araújo Bezerra, J.; Aguiar, J.P.L.; das Chagas do Amaral Souza, F.; Alves Filho, E.G.; Campelo, P.H. Improvement of the Bioaccessibility of Bioactive Compounds from Amazon Fruits Treated Using High Energy Ultrasound. Ultrason. Sonochemistry 2020, 67, 105148. [CrossRef] [PubMed]

27. Chaves, J.O.; de Souza, M.C.; da Silva, L.C.; Lachos-Perez, D.; Torres-Mayanga, P.C.; Machado, A.P.d.F.; Forster-Carneiro, T.; Vázquez-Espinosa, M.; González-de-Peredo, A.V.; Barbero, G.F.; et al. Extraction of Flavonoids From Natural Sources Using Modern Techniques. Front. Chem. 2020, 8, 507887. [CrossRef]

28. Guerrouj, K.; Sánchez-Rubio, M.; Taboada-Rodríguez, A.; Cava-Roda, R.M.; Marín-Iniesta, F. Sonication at Mild Temperatures Enhances Bioactive Compounds and Microbiological Quality of Orange Juice. Food Bioprod. Process. 2016, 99, 20-28. [CrossRef] 
29. Shah, N.N.A.K.; Supian, N.A.M.; Hussein, N.A. Disinfectant of Pummelo (Citrus grandis L. Osbeck) Fruit Juice Using Gaseous Ozone. J. Food Sci. Technol. 2019, 56, 262-272. [CrossRef]

30. Noguera, N.H.; Lima, D.C.; Filho, E.G.A.; Fonteles, T.V.; Rodrigues, S. Influence of Different Non-Thermal Processing on Guava, Orange, and Tangerine Juices and the Food Matrix Effects. Food Bioprocess Technol. 2021, 14, 1662-1672. [CrossRef]

31. Fonteles, T.V.; Leite, A.K.F.; Silva, A.R.A.; Carneiro, A.P.G.; Miguel, E.D.C.; Cavada, B.S.; Fernandes, F.A.N.; Rodrigues, S. Ultrasound Processing to Enhance Drying of Cashew Apple Bagasse Puree: Influence on Antioxidant Properties and in Vitro Bioaccessibility of Bioactive Compounds. Ultrason. Sonochemistry 2016, 31, 237-249. [CrossRef]

32. Torres, B.; Tiwari, B.K.; Patras, A.; Wijngaard, H.H.; Brunton, N.; Cullen, P.J.; O’Donnell, C.P. Effect of Ozone Processing on the Colour, Rheological Properties and Phenolic Content of Apple Juice. Food Chem. 2011, 124, 721-726. [CrossRef]

33. Sroy, S.; Fundo, J.F.; Miller, F.A.; Brandão, T.R.S.; Silva, C.L.M. Impact of Ozone Processing on Microbiological, Physicochemical, and Bioactive Characteristics of Refrigerated Stored Cantaloupe Melon Juice. J. Food Process. Preserv. 2019, 43, e14276. [CrossRef]

34. Zia, S.; Khan, M.R.; Zeng, X.A.; Sehrish, S.; Shabbir, M.A.; Aadil, R.M. Combined Effect of Microwave and Ultrasonication Treatments on the Quality and Stability of Sugarcane Juice during Cold Storage. Int. J. Food Sci. Technol. 2019, 54, $2563-2569$. [CrossRef]

35. Castro-López, C.; Rojas, R.; Ernesto, J.; Sánchez-Alejo, G.N.-M.; Martínez-Ávila, G.C.G. Phenolic Compounds Recovery from Grape Fruit and Phenolic Compounds Recovery from Grape Fruit and By-Products: An Overview of Extraction Methods. In Grape and Wine Biotechnology; Morata, A., Ed.; InTech Open: London, UK, 2016; pp. 103-123.

36. Morales-Blancas, E.F.; Chandia, V.E.; Cisneros-Zevallos, L. Thermal Inactivation Kinetics of Peroxidase and Lipoxygenase from Broccoli, Green Asparagus and Carrots. J. Food Sci. 2002, 67, 146-154. [CrossRef]

37. Abid, M.; Jabbar, S.; Hu, B.; Hashim, M.M.; Wu, T.; Lei, S.; Khan, M.A.; Zeng, X. Thermosonication as a Potential Quality Enhancement Technique of Apple Juice. Ultrason. Sonochemistry 2014, 21, 984-990. [CrossRef] [PubMed]

38. Tiwari, B.K.; O’Donnell, C.P.; Patras, A.; Brunton, N.; Cullen, P.J. Stability of Anthocyanins and Ascorbic Acid in Sonicated Strawberry Juice during Storage. Eur. Food Res. Technol. 2009, 228, 717-724. [CrossRef]

39. Anaya-Esparza, L.M.; Velázquez-Estrada, R.M.; Roig, A.X.; García-Galindo, H.S.; Sayago-Ayerdi, S.G.; Montalvo-González, E. Thermosonication: An Alternative Processing for Fruit and Vegetable Juices. Trends Food Sci. Technol. 2017, 61, 26-37. [CrossRef]

40. Traore, M.B.; Sun, A.; Gan, Z.; Senou, H.; Togo, J.; Fofana, K.H. Antimicrobial Capacity of Ultrasound and Ozone for Enhancing Bacterial Safety on Inoculated Shredded Green Cabbage (Brassica oleracea var. Capitata). Can. J. Microbiol. 2020, 66, 125-137. [CrossRef]

41. Del Rosario García-Mateos, M.; Quiroz-González, B.; Corrales-García, J.; Ybarra-Moncada, M.C.; Leyva-Ruelas, G. Ozone-High Hydrostatic Pressure Synergy for the Stabilization of Refrigerated Pitaya (Stenocereus pruinosus) Juice. Innov. Food Sci. Emerg. Technol. 2019, 56, 102187. [CrossRef]

42. Mason, T.J. Advances in Sonochemistry; Elsevier: Amsterdam, The Netherlands, 1996; Volume 4.

43. Oliveira, V.S.; Rodrigues, S.; Fernandes, F.A.N. Effect of High Power Low Frequency Ultrasound Processing on the Stability of Lycopene. Ultrason. Sonochemistry 2015, 27, 586-591. [CrossRef]

44. Karaca, H.; Velioglu, Y.S. Ozone Applications in Fruit and Vegetable Processing. Food Rev. Int. 2007, 23, 91-106. [CrossRef] 